\title{
The influence of cooked kidney beans (Phaseolus vulgaris) on intestinal cell turnover and faecal nitrogen excretion in the rat
}

\author{
BY SUSAN J. FAIRWEATHER-TAIT, JENNIFER M. GEE \\ AND I. T. JOHNSON* \\ ARC Food Research Institute, Colney Lane, Norwich, Norfolk NR4 7UA
}

(Received 17 August 1982 - Accepted 2 December 1982)

\begin{abstract}
1. Male Wistar rats were fed on semi-synthetic diets containing cooked white kidney beans (Phaseolus vulgaris) or equivalent levels of protein and carbohydrate.

2. No change was observed in over-all nitrogen balance in animals fed on the bean diet, but there was a twoto three-fold increase in their faecal excretion, compared with control rats. This was compensated by a decrease in urinary- $\mathrm{N}$ excretion.

3. Homogenized small intestinal mucosa, prepared from bean-fed animals, showed a $28 \%$ increase in protein content compared with control material.

4. Measurements of ${ }^{3} \mathrm{H}$-labelled thymidine turnover indicated that mucosal cell exfoliation was increased by approximately $35 \%$ in the small intestines of bean-fed rats compared with controls.

5. It is concluded that though a diet rich in cooked $P$. vulgaris leads to some increase in mucosal cell turnover in the small intestine of rats, the consequent increase in mucosal protein loss could not account for the increased faecal- $\mathrm{N}$ excretion seen in these animals.
\end{abstract}

Although many legumes are rich sources of protein, their nutritional value for man appears to be somewhat limited by their low digestibility. In animal studies, values as low as 0.70 were obtained for white kidney beans (Phaseolus vulgaris) compared with values in excess of 0.90 for sources such as wheat and beef (Burr, 1975). These estimates are derived from experimental studies in which the endogenous-nitrogen excretion of rats fed on a protein-free diet is subtracted from $\mathbf{N}$ excretion during consumption of the protein source under study. The remainder is usually assumed to represent unabsorbed dietary protein. The low availability of legume protein has been ascribed either to the presence in pulses of heat-resistant protease inhibitors, or to a tendency for the proteins to form insoluble complexes with other, unavailable constituents of the seeds (Sgarbieri et al. 1979).

An alternative explanation for the seemingly-low protein digestibility of legumes is that the excretion of endogenous $\mathrm{N}$ is itself increased by their consumption (Shurpalekar et al. 1979). Thus, although the dietary protein might in fact be fully digested and absorbed, this would be partially offset by an increased production and faecal excretion of nitrogenous material from the digestive tract. A similar mechanism was proposed by McCance \& Walsham (1948) to account for the increased faecal excretion of $\mathrm{N}$ in subjects consuming wheat flour of high extraction rates.

In a recent report, Bender \& Mohammidiha (1981) have proposed that the increased faecal $\mathrm{N}$ of rats fed on a diet containing legumes could be due to an enhancement of mucosal cell turnover rather than low protein digestibility. In their study, the faecal excretion of DNA and $\mathrm{N}$ in animals fed on cooked white kidney beans was compared with that of animals fed on either a protein-free diet, or a diet containing casein. Since the large increase in DNA and $\mathrm{N}$ excretion by bean-fed animals could not, apparently, be fully accounted for by the increased faecal bacterial mass, it was concluded that the elevated excretion must have resulted from increased mucosal cell loss. Such an effect would have important nutritional and physiological implications. We have, therefore, sought to test the suggestions directly, by looking for changes in mucosal cell turnover at various sites in the gastrointestinal tract

* For reprints. 
Table 1. Composition of experimental diets $(\mathrm{g} / \mathrm{kg})$

(Values in parentheses indicate amounts used in Expts 1 and 2)

\begin{tabular}{lcc}
\hline & Control & $\begin{array}{c}\text { White kidney } \\
\text { bean }\end{array}$ \\
\hline Casein & $162(200)$ & $65(100)$ \\
Starch & $329(310)$ & $177.5(160)$ \\
Sucrose & $329(310)$ & $177.5(160)$ \\
Maize oil & 80 & 80 \\
Solka floc & 40 & 40 \\
Minerals* & 40 & 40 \\
Vitamin mix $\dagger$ & 20 & 20 \\
Dried beans & 0 & 400 \\
Dietary fibre & $56 \cdot 2$ & $185 \cdot 8$ \\
Nitrogen & $23.9(27.0)$ & $24.6(28.8)$ \\
\hline \hline
\end{tabular}

* Minerals (g/kg diet); $\mathrm{CaHPO}_{4} 13 \cdot 00, \mathrm{CaCO}_{3} 8 \cdot 20, \mathrm{KCl} 7 \cdot 03, \mathrm{Na}_{2} \mathrm{HPO}_{4} 7 \cdot 40, \mathrm{MgSO}_{4} \cdot \mathrm{H}_{2} \mathrm{O} 4 \cdot 00, \mathrm{MnSO}_{4} \cdot \mathrm{H}_{2} \mathrm{O}$ $0 \cdot 18, \mathrm{ZnCO}_{3} 0 \cdot 10, \mathrm{FeSO}_{4} \cdot 7 \mathrm{H}_{2} \mathrm{O} 0 \cdot 144, \mathrm{CuSO}_{4} 0.015, \mathrm{KIO}_{3} 0 \cdot 001$.

† Vitamin mix (mg/kg diet): nicotinic acid 60, cyanocobalamin in mannitol 50 , calcium D-pantothenate 40 , thiamin hydrochloride 10 , riboflavin 10, pteroylmonoglutamic acid 5, D-biotin 1, menadione 1, Rovimix E-25 (Roche) 300, Rovimix A-500 (Roche) 25, Rovimix A-500/D3 (Roche) 15, choline bitartrate 1800 .

of rats fed on diets rich in white kidney beans. Cell turnover was monitored by observing the uptake and subsequent loss of tritium from the labelled DNA precursor, thymidine (methyl $\left[{ }^{3} \mathrm{H}\right]$ thymidine; ${ }^{3} \mathrm{H}-\mathrm{Td} \dot{\mathrm{R}}$ ). A brief report containing preliminary findings of this study has appeared elsewhere (Fairweather-Tait et al. 1982).

\section{MATERIALS AND METHODS}

\section{Diets}

Locally-purchased dried white kidney beans were soaked for $24 \mathrm{~h}$ in water and cooked for $15 \mathrm{~min}$ at $15 \mathrm{psi}$. The cooked beans were oven-dried at $60^{\circ}$ for the $\mathrm{N}$ balance and mucosal function studies, or freeze-dried for the mucosal cell turnover study, and then milled and passed through a $1 \mathrm{~mm}$ sieve. The compositions of the control and test diets used in each experiment are given in Table 1.

\section{Expt 1. $N$ balance}

A preliminary study was carried out in which $\mathrm{N}$ balance in rats fed on a diet containing cooked, dried white kidney beans was compared with that in rats fed on a semi-synthetic diet containing a similar level of protein from casein. The animals (five mature Wistar rats/ group; mean weight 347 (SE 33) g) were housed in stainless steel metabolism cages with plastic funnels for separate collection of urine and faeces over a $4 \mathrm{~d}$ period. Daily urine collections from each animal were combined, the total volume was measured and $\mathrm{N}$ determinations carried out on appropriate portions. Similarly-pooled faecal samples were wet-homogenized in a vortex blender before $\mathrm{N}$ analysis.

\section{Expt 2. Mucosal function}

The effect of the bean diet on some aspects of mucosal composition and function was examined by comparing protein and DNA content and disaccharidase activity in jejunal mucosa from bean-fed and control animals. A simultaneous assessment of food intake, growth and faecal-N excretion was also carried out in the two groups. Twenty-six male Wistar rats were weighed and housed individually in wire-bottomed cages and fed on either 
the bean diet (thirteen animals) or the control diet (thirteen animals) and water ad lib. The total food intake and faecal output of animals in both groups were measured over a $10 \mathrm{~d}$ period (days 2-11 inclusive). On day 15, seven animals from each group were weighed and killed by stunning and cervical fracture. On day 17 the remaining six animals in each group were weighed and similarly killed, and the entire small intestine of each animal was removed through a mid-line abdominal incision, rinsed and extended on the bench with minimal stretching. The first $100 \mathrm{~mm}$ distal to the pyloric sphincter was discarded and the next $100 \mathrm{~mm}$ was collected for DNA analysis. A further $50 \mathrm{~mm}$ of jejunum was excised and the next $250 \mathrm{~mm}$ was collected for protein and disaccharidase assay. Segments of jejunum collected for analysis were slit open, rinsed with isotonic saline $(9 \mathrm{~g}$ sodium chloride $/ \mathrm{l})$ and laid mucosa upwards on a glass plate. The mucosa was then scraped from the underlying muscle layers with a microscope slide.

\section{Expt 3. Mucosal cell turnover}

For the comparison of mucosal cell turnover in bean-fed and control animals, seventy-two male Wistar rats (126-150 g initial weight) were randomly divided into two groups, placed individually in wire-bottomed cages, and fed on test or control diets ad lib. as before. After $7 \mathrm{~d}$ each animal received a $50 \mu \mathrm{Ci}$ dose of ${ }^{3} \mathrm{H}-\mathrm{TdR}$ (43 Ci/mmol; Amersham International, Amersham, Bucks) by intraperitoneal injection. Twelve rats from each group were killed after 24,48 and $72 \mathrm{~h}$, the times of injection and killing being synchronized to ensure the accuracy of these periods. Each animal's faeces were collected from the time of injection to the time of killing and combined with the colonic and rectal contents. The entire small intestine was removed, measured and rinsed in saline. Samples of jejunum and ileum were obtained by discarding the proximal $150 \mathrm{~mm}$ and distal $100 \mathrm{~mm}$ from each small intestine, and collecting a $300 \mathrm{~mm}$ segment from each end of the remaining length. The colon and rectum were removed, emptied, rinsed and weighed. All the tissue was dried to constant weight at $85^{\circ}$, and the jejunal and ileal samples, the colons and the dried faecal samples were analysed for ${ }^{3} \mathrm{H}$ content.

In the case of four animals it was found that all three tissue samples had an unusually low activity in comparison with the group mean, whilst the corresponding faecal activities were greatly increased. This effect would be expected if the ${ }^{3} \mathrm{H}-\mathrm{TdR}$ injection had entered the bowel rather than the intraperitoneal space and had been largely voided in the faeces. This was assumed to be the case and, in the final presentation of the results, one control and three bean-fed animals were excluded. In each case, the excluded tissue activity lies between 2 SD and 6 SD below the modified mean, whilst the corresponding faecal activities lie more than $20-35 \mathrm{SD}$ above the modified mean.

In a separate experiment, the time-course for the faecal excretion of ${ }^{3} \mathrm{H}$ from thymidine was investigated. Three male Hooded rats were given a $50 \mu \mathrm{Ci}$ dose of ${ }^{3} \mathrm{H}-\mathrm{TdR}$ as before, housed individually in wire-bottomed cages, and fed on standard laboratory chow (CRM; Labsure Ltd, Poole, Dorset). Faeces were collected at approximately $12 \mathrm{~h}$ intervals over a period of $101 \mathrm{~h}$ after the injection. Each sample was dried and analysed individually for ${ }^{3} \mathrm{H}$.

\section{Statistics}

All results are presented as mean values with their standard errors. The significance of differences between means was assessed by Student's unpaired $t$ test.

\section{Analytical methods}

$N$. The $\mathrm{N}$ contents of diets, faeces and urine were determined using the Kjeldahl method. The protein content of the diet was calculated using a conversion factor of 6.38 for casein and $5 \cdot 71$ for beans. 
Protein. The protein content of scraped mucosal samples was determined using a method based on the Biuret reaction, as described by Herbert et al. (1971). Each mucosal scrape was homogenized for $2 \mathrm{~min}$ in $0.22 \mathrm{M}$-potassium phosphate buffer, $\mathrm{pH} 7.4(1: 4 \mathrm{w} / \mathrm{v})$ at approximately $0^{\circ}$, and stored at $-20^{\circ}$ before analysis. The dry matter content of the homogenates was determined by oven-drying $\left(85^{\circ}\right)$ samples of known volume to constant weight, a correction being made for the contribution of the buffer.

$D N A$. The analyses were carried out on mucosal scrapes prepared from $100 \mathrm{~mm}$ lengths of jejunum. The weighed samples were freeze-dried and reweighed, and the DNA was extracted from $50 \mathrm{mg}$ subsamples by the method of Hofert \& White (1968). Freeze-drying has been shown to give equivalent results to oven-drying in intestinal tissue (Lucas \& Johnson, 1974). The DNA content was determined by a colorimetric assay using indole, as described by Hubbard et al. (1970).

Maltase (EC 3.2.1.20), lactase (EC 3.2 .1 .23) and sucrase (EC 3.2 .1 .48). The enzyme activities of the homogenized mucosal scrapes described previously were determined using a modification of the methods of Dahlqvist (1964) and Messer \& Dahlqvist (1966). Portions of mucosal homogenate were incubated with the appropriate substrate in $0.22 \mathrm{M}-\mathrm{KH}_{2} \mathrm{PO}_{4}$, $\mathrm{pH} 6.0$, at $37^{\circ}$. After a suitable period the reaction was stopped and the supernatant fraction assayed for glucose by the glucose oxidase-peroxidase method. Enzyme activities were expressed as $\mu \mathrm{mol}$ substrate hydrolysed/mg protein per min.

${ }^{3} \mathrm{H}$. Radioactivity was determined by liquid-scintillation counting. The dried and weighed colons and segments of jejunum and ileum were digested in concentrated nitric acid $(0.4-1.0 \mathrm{ml})$ at $70^{\circ}$. Digested samples $(0.4 \mathrm{ml})$ were made up to $4 \mathrm{ml}$ with $0.75 \mathrm{M}$-Trizma base (Sigma, Poole, Dorset) in water and $0.5 \mathrm{ml}$ portions added, together with $0.5 \mathrm{ml}$ distilled water, to $9 \mathrm{ml}$ scintillant (Cocktail T, Scintran; BDH, Poole, Dorset) before counting in a Philips PW4700 liquid scintillation counter with automatic quench correction and counting efficiency determined by external standard channels ratio.

Faecal samples were dried at $60^{\circ}$ in a fan oven for $48 \mathrm{~h}$; the collections from the mucosal cell turnover study were then ground in a Moulinex grinder and subsamples taken for analysis. Ground samples or dried pellets were combusted by means of a Harvey Biological Oxidiser type OX400 (Laboratory Impex Ltd, Twickenham). The tritiated water thus released was absorbed directly into $15 \mathrm{ml}$ Harvey Tritium Cocktail containing approximately $0.25 \mathrm{ml}$ methyl alcohol, transferred to vials and counted as described previously.

Dietary fibre. The fibre contents of the diets were determined by a modification (M. A. White and D. A. T. Southgate, personal communication) of the Southgate method (Southgate, 1969).

\section{RESULTS}

\section{Expt 1}

No significant difference was observed in the over-all $\mathrm{N}$ balance of bean-fed animals, compared with a control group over a $4 \mathrm{~d}$ experimental period (Table 2). There was a significant rise in the faecal excretion of $\mathrm{N}$ by the bean-fed animals, this being largely compensated for by a reduction in urinary- $\mathrm{N}$ excretion which was not, however, shown to be statistically significant.

\section{Expt 2}

During this experiment, the test group received the bean diet for up to $17 \mathrm{~d}$. All the animals remained healthy and there was no significant difference in the average food consumptions of the two groups over a $10 \mathrm{~d}$ period nor in their final weights. The total dry weight of faeces produced by the bean-fed group was 2.4 times higher than that of the controls, and this was accompanied by a $2 \cdot 9$-fold increase in faecal-N excretion. 
Table 2. Expt 1. Nitrogen balance in bean-fed and control animals over a $4 d$ period (Values are means with their standard errors for five animals in each group)

\begin{tabular}{|c|c|c|c|c|c|}
\hline & \multirow{2}{*}{\multicolumn{2}{|c|}{ Control group }} & \multicolumn{3}{|c|}{ Bean-fed group } \\
\hline & & & \multirow[b]{2}{*}{ Mean } & \multirow[b]{2}{*}{$\mathbf{S E}$} & \multirow{2}{*}{$\begin{array}{c}\text { Signifi- } \\
\text { cance } \\
\text { of } \\
\text { difference }\end{array}$} \\
\hline & Mean & $\mathrm{SE}$ & & & \\
\hline $\mathrm{N}$ intake $(\mathrm{g})$ & 2.74 & $0 \cdot 14$ & 2.79 & $0 \cdot 25$ & NS \\
\hline Urinary-N excretion (g) & 1.98 & 0.36 & 1.66 & $0 \cdot 24$ & NS \\
\hline Faecal-N excretion $(\mathrm{g})$ & 0.24 & 0.02 & 0.61 & 0.03 & $* * *$ \\
\hline Total-N excretion (g) & $2 \cdot 22$ & $0 \cdot 34$ & $2 \cdot 28$ & 0.25 & NS \\
\hline Retained N (g) & 0.52 & 0.38 & 0.52 & $0 \cdot 23$ & NS \\
\hline
\end{tabular}

NS, not significant; ${ }^{* * *} P<0 \cdot 001$.

Table 3. Expt 2. Faecal nitrogen excretion in bean-fed and control animals and a comparison of some aspects of small intestine composition and function

(Values are means with their standard errors; number of animals shown in parentheses)

\begin{tabular}{|c|c|c|c|c|c|}
\hline & \multirow{2}{*}{\multicolumn{2}{|c|}{ Control group }} & \multicolumn{3}{|c|}{ Bean-fed group } \\
\hline & & & \multirow[b]{2}{*}{ Mean } & \multirow[b]{2}{*}{ SE } & \multirow{2}{*}{$\begin{array}{l}\text { Signifi- } \\
\text { cance } \\
\text { of } \\
\text { difference }\end{array}$} \\
\hline & Mean & $\mathrm{SE}$ & & & \\
\hline Final body-wt (g) & $234 \cdot 3$ & $3.7(13)$ & $236 \cdot 9$ & $3.9(13)$ & NS \\
\hline Food intake $(\mathrm{g} / 10 \mathrm{~d})$ & $209 \cdot 4$ & $16(13)$ & 214.7 & $22(13)$ & NS \\
\hline Dry wt of faeces $(g / 10 d)$ & $13 \cdot 6$ & $2 \cdot 1(13)$ & $33 \cdot 1$ & $7 \cdot 5(13)$ & $* * *$ \\
\hline Faecal-N excretion $(\mathrm{g} / 10 \mathrm{~d})$ & 0.42 & $0 \cdot 11(13)$ & 1.24 & $0.20(13)$ & $* * *$ \\
\hline Mucosal DNA (mg/g) & $18 \cdot 5$ & $0.7(6)$ & $21 \cdot 4$ & $1 \cdot 2(6)$ & NS \\
\hline Mucosal protein $(\mathrm{mg} / \mathrm{g})$ & 704 & $65(6)$ & 886 & $35(6)$ & $*$ \\
\hline Protein:DNA & 38.6 & $4 \cdot 5(6)$ & $41 \cdot 7$ & $1.9(6)$ & NS \\
\hline \multicolumn{6}{|c|}{ Disaccharidase activity ( $\mu \mathrm{m}$ substrate hydrolysed/mg protein per $\mathrm{min}$ ) } \\
\hline Maltase & 0.017 & $0.001(6)$ & $0 \cdot 019$ & $0.002(6)$ & NS \\
\hline Lactase & 0.010 & $0.001(6)$ & 0.012 & $0.002(6)$ & NS \\
\hline Sucrase & 0.009 & $0.002(6)$ & 0.010 & $0.002(6)$ & NS \\
\hline
\end{tabular}

NS, not significant. Means were significantly different from control values: ${ }^{*} P<0.05, \quad{ }^{* * *} P<0.001$.

Small changes were observed in the compositions of the intestinal mucosae from the two groups. The bean-fed animals showed a $16 \%$ increase in DNA per unit dry weight of mucosal homogenate and a $26 \%$ increase in the protein content. No differences were detected, however, in the maltase, lactase or sucrase activities of the two groups. The results are summarized in Table 3.

\section{Expt 3}

The measurements of intestinal lengths and weights from animals killed on successive days in this experiment were combined to provide evidence of any morphological changes brought about by the bean diet. The length of the small intestine was the same in both the control $(1080 \pm 9 \mathrm{~mm})$ and bean-fed $(1080 \pm 11 \mathrm{~mm})$ groups. However, there was a small reduction in the dry weight of small intestine in the bean-fed $(1.69 \pm 0.04 \mathrm{~g})$ animals 


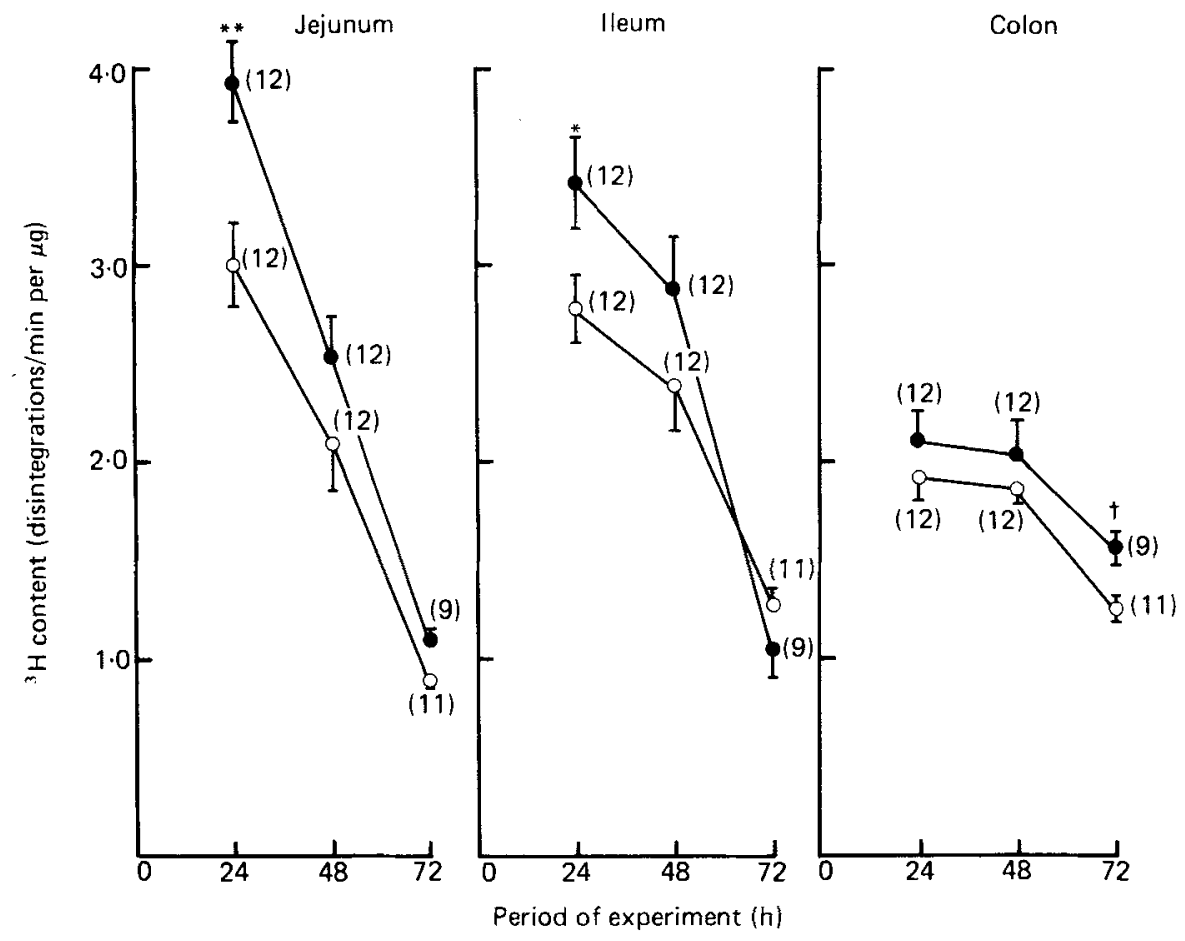

Fig. 1. Expt 3. The tritium content of intestinal tissue from bean-fed $(O)$ and control-fed $(O)$ rats killed at $24 \mathrm{~h}$ intervals after an intraperitoneal injection of methyl[ $\left.{ }^{3} \mathrm{H}\right]$ thymidine. Points are mean values, with their standard errors represented by vertical bars, for single samples taken from the number of animals shown in parentheses. $* P<0.05, \quad \nmid P<0.02, * * P<0.01$.

compared with controls $(1.82 \pm 0.05 \mathrm{~g})$, whilst the weight of the colon and rectum in the bean-fed animals $(0.27 \pm 0.01 \mathrm{~g})$ was increased compared with controls $(0.24 \pm 0.01 \mathrm{~g})$. Both these differences were statistically significant $(P<0.05$ and $P<0.01$ respectively).

The mean ${ }^{3} \mathrm{H}$ activity/g dry weight of tissue from jejunum, ileum and colon of animals killed on successive days after the injection of ${ }^{3} \mathrm{H}-\mathrm{TdR}$ is shown in Fig. 1. Clearly, the ${ }^{3} \mathrm{H}$ activity of all the intestinal samples declined significantly over the $48 \mathrm{~h}$ experimental period, indicating, as expected, a loss of cells from the labelled mucosal pool. There was an over-all tendency for the tissues from the bean-fed group to have a higher ${ }^{3} \mathrm{H}$ activity than the controls, this difference being significant in the case of the small intestines of the $24 \mathrm{~h}$ groups and the colons of the $72 \mathrm{~h}$ groups.

The differences between the day 1 and day 3 values for jejunum and ileum (Fig. 1) were calculated and averaged to provide an estimate for the decline in ${ }^{3} \mathrm{H}$ activity/g of small intestine in the two groups. These figures, when corrected for the average total dry weight of intestine, indicated that the loss of ${ }^{3} \mathrm{H}$ from thymidine, and hence of labelled DNA, was some $35 \%$ higher in the bean-fed animals than in the controls. By a similar calculation it was estimated that the loss of ${ }^{3} \mathrm{H}$ from the colon was $6 \%$ lower in test animals than in controls.

The levels of ${ }^{3} \mathrm{H}$ appearing in the faeces of the two groups of animals up to the time of death is shown in Fig. 2. There was a progressive excretion of ${ }^{3} \mathrm{H}$ in the faeces throughout the $72 \mathrm{~h}$ following administration of ${ }^{3} \mathrm{H}-\mathrm{TdR}$; the levels were somewhat higher in the bean-fed animals than the controls. An aid to the interpretation of this graph is provided by Fig. 3, which illustrates the time course for the faecal excretion of ${ }^{3} \mathrm{H}$ from ${ }^{3} \mathrm{H}-\mathrm{TdR}$ in rats fed on a conventional pellet diet. 


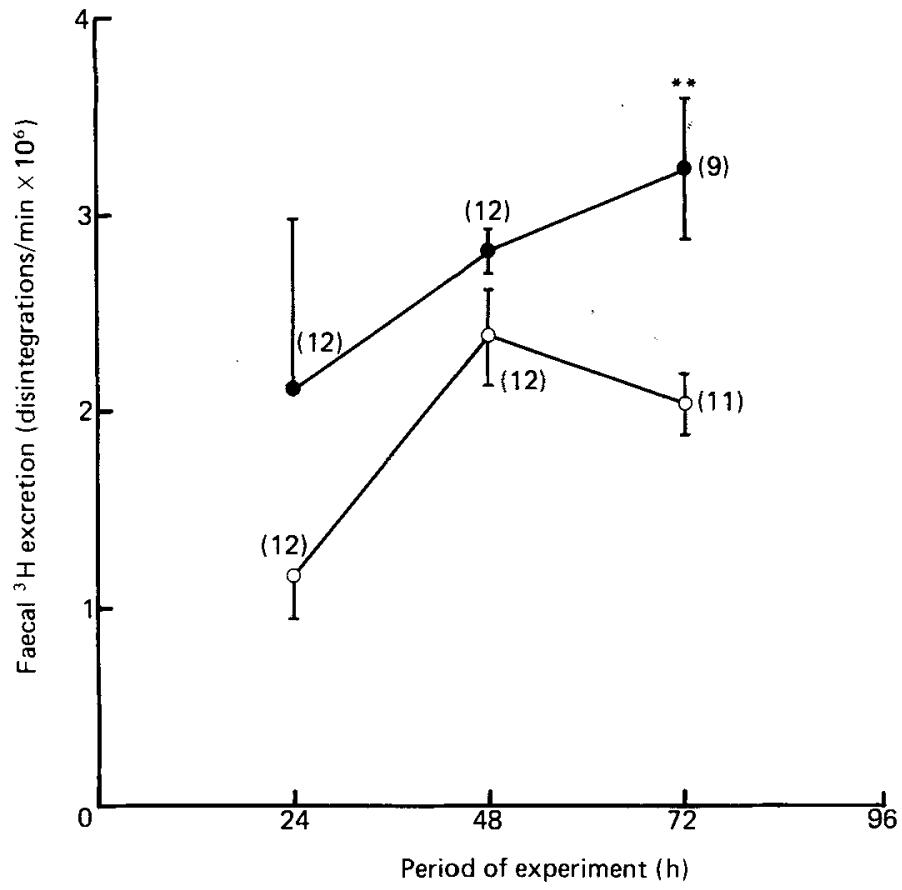

Fig. 2. Expt 3. The total faecal excretion of tritium by rats killed at $24 \mathrm{~h}$ intervals after an intraperitoneal injection of methyl[ $\left.{ }^{3} \mathrm{H}\right]$ thymidine. Points are mean values, with their standard errors represented by vertical bars, for faecal samples from the number of bean-fed $(\Theta)$ or control-fed $(O)$ animals shown in parentheses. ${ }^{* *} P<0.01$.

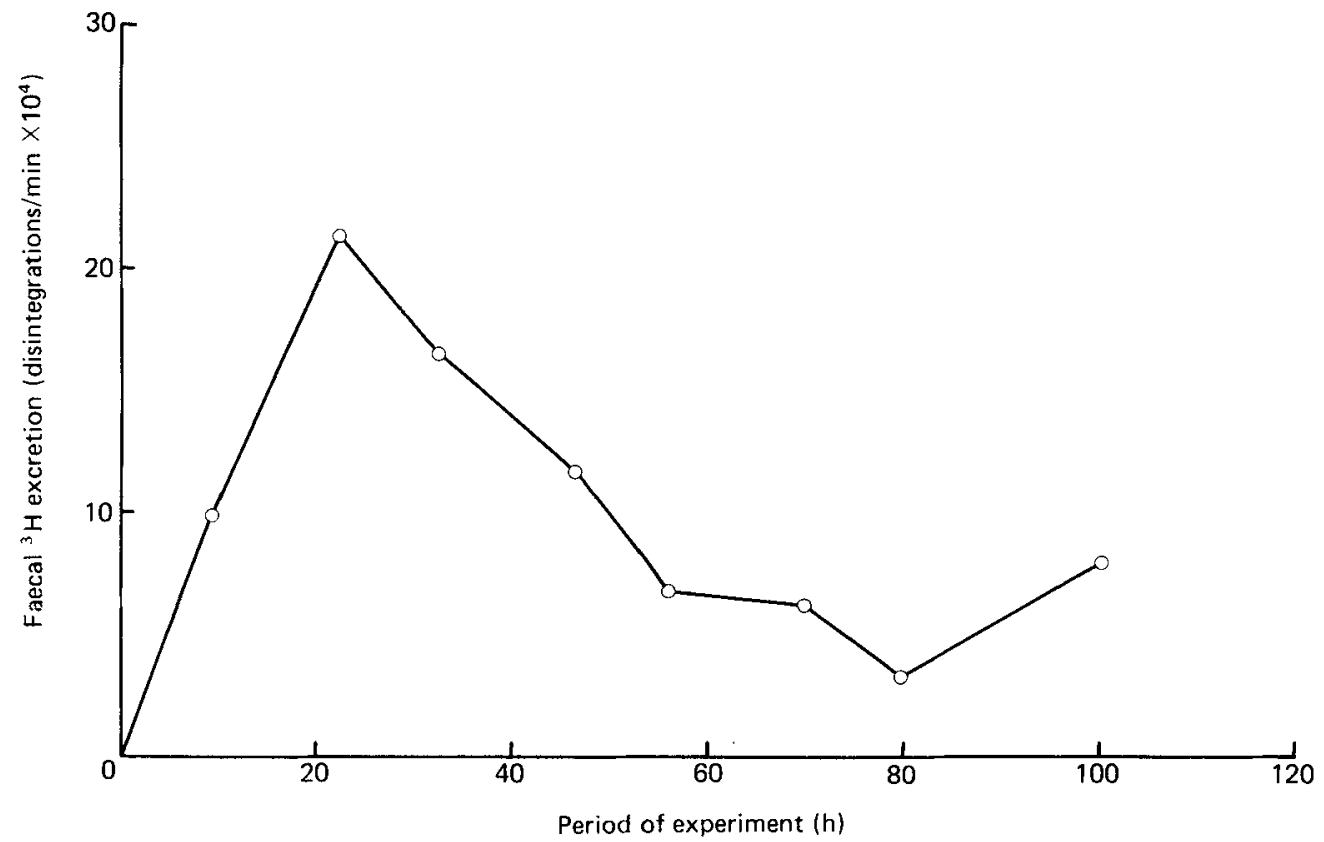

Fig. 3. Expt 3. The time-course of faecal excretion of tritium by rats fed on a commercial pelleted diet, following an intraperitoneal injection of methyl[ $\left.{ }^{3} \mathrm{H}\right]$ thymidine. Points are the mean values for faecal samples from three animals. 


\section{DISCUSSION}

The continuous proliferation and loss of enterocytes, coupled with the production of digestive enzymes and mucus, places the intestinal mucosa amongst the principal sites of protein turnover in the body (Alpers \& Kinzie, 1973). It has been estimated that in the rat, $90 \%$ of the endogenous protein production is available for reabsorption (Twombly \& Meyer, 1961), and one school of thought holds that the secreted protein pool exceeds the dietary protein intake by several-fold and thus serves to stabilize the amino acid composition of the luminal contents (Nasset \& Ju, 1961). Recently, the interesting suggestion has been made that much of the faecal $\mathrm{N}$ of rats fed on white kidney beans might be the result of greatly increased cell turnover (Bender \& Mohammidiha, 1981). If true, this would imply either that mucosal proliferation had become so much increased as to overwhelm the normal reabsorption process, or that the digestive and absorptive mechanisms of the gut were themselves impaired. Although the toxic effects of many raw legumes are well-known (Aykroyd et al. 1981), the possibility that cooked beans might bring about such dramatic changes in normal intestinal function was thought to merit further study.

The conclusions of Bender \& Mohammidiha (1981) were based on measurements of DNA: $N$ in the faeces of rats fed on various diets, and on estimates of the numbers of viable bacteria in their faecal flora. This approach is open to criticism on methodological grounds. For example, the use of Escherichia coli as a representative organism for the calculation of the total faecal bacterial numbers is of doubtful validity (Clarke, 1977). In any case, it is difficult to draw conclusions as to particular physiological mechanisms on the basis of such indirect observations. In the present study, therefore, we have re-examined this question, using the turnover of tritium from thymidine as a direct indicator of relative rates of mucosal cell renewal in bean-fed and control animals. The technique employed was based on that of Steel \& Lamerton (1965) and depends on the principle that the DNA of dividing cells may be securely labelled with ${ }^{3} \mathrm{H}$ from thymidine during the relatively-short period between the administration of the dose and its subsequent metabolic breakdown. The ${ }^{3} \mathrm{H}$ activity of the proliferating tissue remains stable as the labelled cells mature, and then declines as they progress to senescence and are lost from the population. This method provides a sensitive means of detecting differences in over-all cell turnover, though it does not provide information about the kinetics of the underlying processes of cell division and migration.

The bean diet used in the present study was readily accepted by the experimental animals, which continued to thrive on it for over 2 weeks. As expected, there was a large increase in the dry weight and $\mathrm{N}$ content of their faeces, but because of what was, in effect, a compensating drop in their urinary- $\mathrm{N}$ excretion, the bean-fed rats remained in over-all $\mathrm{N}$ balance. Similar observations have been reported by other workers who used animals fed on diets rich in various types of unavailable polysaccharide, specifically guar gum, carob bean gum and sodium alginate (Harmuth-Hoene \& Schwerdtfeger, 1979). A negative correlation between urinary- and faecal- $\mathrm{N}$ losses has also been reported in humans consuming diets of differing fibre content (Cornu \& Delpeuch, 1981). Such an effect could, conceivably, indicate an adaptive response, compensating for an increased loss of $\mathrm{N}$ via some other route of excretion. This possibility requires further investigation, but lies beyond the scope of the present study.

The ${ }^{3} \mathrm{H}$ activity contained in samples of jejunum, ileum and colon, taken from test and control animals at three different times after the administration of thymidine, is illustrated in Fig. 1. For clarity, the points are joined by straight lines, but it must be remembered that they would be expected to lie on smooth curves. According to Steel \& Lamerton (1965), these curves display an initial plateau, lasting for $30-36 \mathrm{~h}$ in the jejunum and somewhat 
longer in the colon. In the present study, the sampling times were chosen so that the first measurement would lie within this period to provide an estimate of initial thymidine uptake. This appears to have been achieved in the ileum and colon but, since the decline in jejunal ${ }^{3} \mathrm{H}$ activity is linear, it probably commenced before the first sample was taken. At all three sites the tissue from bean-fed animals showed a higher initial activity than the controls, and the differences were statistically significant in the small intestine.

In Expt 2 it was shown that both protein and DNA tended to increase as a proportion of mucosal dry weight in the bean-fed animals, and reached a surprisingly high level. This change, incidently, reflected a reduced dry weight:wet weight value of the mucosal homogenate, indicating a decline in some non-protein constituent. Since there was no significant difference in DNA: protein between the two groups, the estimated $35 \%$ greater loss of mucosal DNA from the bean-fed animals also provides an approxirate indication of the probable production of endogenous protein by cell exfoliation over the same period.

Estimation of the rate of appearance of ${ }^{3} \mathrm{H}$ in the faeces of the two groups was carried out as a second method of comparing their losses of mucosal DNA. These results were rather variable, but the cumulative ${ }^{3} \mathrm{H}$ excretion was higher in the bean-fed animals than in the controls at the three observation times and this tends to suggest an increase in the faecal excretion of DNA. Caution is needed in the interpretation of these results, however. When the time-course of excretion of ${ }^{3} \mathrm{H}$ from thymidine was examined in a small group of control animals fed on a standard pellet diet, it was found that the maximum rate occurred at approximately $24 \mathrm{~h}$ after the administration of thymidine. Since this is before the loss of labelled mucosal cells begins, it is unlikely that mucosal debris is the main source of faecal ${ }^{3} \mathrm{H}$. A probable explanation is that the breakdown products from metabolized thymidine, tritiated water for example, become available to the gastrointestinal flora which incorporate them into the faeces soon after administration of the dose. The greater faecal bulk of the bean-fed animals probably indicates greater numbers of bacterial cells, leading in turn to higher levels of ${ }^{3} \mathrm{H}$ incorporation in the faeces. Any free tritiated water would, of course, be lost from the faeces during oven-drying.

The increased thymidine incorporation, and the higher levels of DNA and protein in the small intestinal mucosa of bean-fed rats, suggest a moderate increase in cell proliferation. This effect need not be specifically due to the consumption of beans however, as there is evidence that similar changes occur in animals fed on diets rich in unavailable polysaccharides. For example, Brown et al. (1979) have shown that the consumption of pectin appears to be associated with crypt hyperplasia in the small intestine of rats. Furthermore, Ecknauer et al. (1981) have reported that a reduction in mucosal cell renewal occurs in rats fed on an elemental diet compared with that in animals eating a standard laboratory chow; however, rates of cell renewal were partially restored by the addition of cellulose to the diet as a bulking agent. The enhancement of cell proliferation in the small intestinal mucosa of the bean-fed rats in this study may, therefore, result from their markedly increased dietary fibre intake.

Our estimate of a $35 \%$ increase in protein loss due to increased cell turnover is, of course, only an indication of the amount appearing in the small intestinal lumen from this source, and one would expect that most of the extra protein would be available for digestion and reabsorption. Furthermore, if, as other workers have estimated, only $8-15 \%$ of the protein secreted by the small intestine originates from cell exfoliation (DaCosta et al. 1971), then clearly this source could not account for the two-to three-fold increase in faecal- $\mathrm{N}$ excretion seen in the present study. No evidence was obtained for any enhancement of cell turnover in the colon, where reabsorption would not occur. We conclude, therefore, that our results do not support the suggestion that the low digestibility of cooked beans is occasioned by their effect on mucosal cell turnover. It is probable that faecal $\mathrm{N}$ represents a complex 
end-product of the activities of the intestinal flora, which draw on many sources of nitrogenous material, both endogenous and dietary. Though increased mucosal cell loss seems unlikely to be a major source of enhanced faecal- $N$ excretion, this does not rule out other endogenous sources, and further work is needed to explain the origins of this material.

The authors wish to thank Ms V. Simmonds, Mrs W. E. Nelson and Miss J. Brown for skilled technical assistance at various stages in this work.

\section{REFERENCES}

Alpers, D. H. \& Kinzie, J. L. (1973). Gastroenterology 64, 471.

Aykroyd, W. R., Doughty, J. \& Walker, A. F. (1981). FAO Nutr. Stud. no. 19.

Bender, A. E. \& Mohammidiha, H. (1981). Proc. Nutr. Soc. 40, 66A.

Brown, R. C., Kelleher, J. \& Losowsky, M. S. (1979). Br. J. Nutr. 42, 357.

Burr, H. K. (1975). In Protein Nutritional Quality of Foods and Feeds, pt 2, p. 119 [Mendel Friedman, editor]. New York: Marcel Dekker.

Clarke, R. T. J. (1977). Microbial Ecology of the Gut. London and New York: Academic Press.

Cornu, A. \& Delpeuch, F. (1981). Am. J. clin. Nutr. 34, 2454.

DaCosta, L. R., Croft, D. N. \& Creamer, B. (1971). Gut 12, 179.

Dahlquist, A. (1964). Analyt. Biochem. 7, 18.

Ecknauer, R., Sircar, B. \& Johnson, L. R. (1981). Gastroenterology 81, 781.

Fairweather-Tait, S. J., Gee, J. M., Johnson, I. T. \& Nelson, W. E. (1982). Proc. Nutr. Soc, 41, 49A.

Harmuth-Hoene, A. E. \& Schwerdtfeger, E. (1979). Nutr. Metab. 23, 399.

Herbert, D., Phipps, P. J. \& Strange, R. E. (1971). Methods in Microbiology, vol. 5B, p. 244. London and New York: Academic Press.

Hofert, J. F. \& White, A. (1968). Endocrinology 82, 767.

Hubbard, R. W., Matthew, W. T. \& Dubowik, D. A. (1970). Analyt. Biochem. 38, 190.

Lucas, M. L. \& Johnson, I. T. (1974). Experientia 30, 1487.

McCance, R. A. \& Walsham, C. M. (1948). Br. J. Nutr. 2, 26.

Messer, M. \& Dahlquist, A. (1966). Analyt. Biochem. 14, 376.

Nasset, E. S. \& Ju, J. S. (1961). J. Nutr. 74, 461.

Sgarbieri, U.S., Antunes, P. L. \& Almeida, L. D. (1979). J.Fd Sci. 44, 1306.

Shurpalekar, K. S., Sandaravalli, O. E. \& Rao, M. N. (1979). Nutr. Rep. Int. 19, 119.

Southgate, D. A. T. (1969). J. Sci. Fd. Agric. $20,331$.

Steel, G. G. \& Lamerton, L. F. (1965). Exp. Cell Res. 37, 117.

Twombly, J. \& Meyer, J. H. (1961). J. Nutr. 74, 453. 